\title{
Original Article (原静秴文)
}

\section{Population Trend Estimation of Three Threatened Bird Species in Japanese Rural Forests: the Japanese Night Heron Gorsachius goisagi, Goshawk Accipiter gentilis and Grey-faced Buzzard Butastur indicus}

\author{
Kazuto Kawakami* and Hiroyoshi Higuchi**
}

\begin{abstract}
The population trends of the Japanese Night Heron Gorsachius goisagi, the Goshawk Accipiter gentilis and the Grey-faced Buzzard Butastur indicus were estimated based on records of the number of individuals kept in Japanese zoos since the 1960s. Because no special effort is made to collect these species, and because they seldom breed in captivity, their population changes in zoos were assumed to reflect that of the wild populations. In order to reinforce the zoo data, we collected local records of the population trends of these three species in Niigata Prefecture, Tochigi Prefecture, Cape Irago of Aichi Prefecture and the Miyako Islands of Okinawa Prefecture. The results indicated that at all investigated localities, except Tochigi Prefecture, the Japanese Night Heron and the Grey-faced Buzzard had decreased in numbers since the 1960s, whereas the Goshawk had increased in number nationwide. There is, however, a possibility that the increase in the Goshawk population is an overestimation, and it is necessary to investigate its wild population trend in detail. The most likely cause of the declines of the Japanese Night Heron and the Grey-faced Buzzard is habitat degradation, both in quality and in quantity. To date, these two species have not been the targets of any concerted conservation effort, but they must henceforth be accorded this status.
\end{abstract}

Key words: Goshawk, Grey-faced Buzzard, Japanese Night Heron, Japanese Red Data Book, Population trends.

$$
\text { キーワード：オオタカ, サシバ, ミゾゴイ, レッドデータブック, 個体数推移. }
$$

\section{Introduction}

Recently, the conservation of rural lowland forest with the neighboring paddy field (SATOYAMA in Japanese) is regarded as an important subject in Japan (Takeuchi et al. 2001, Washitani 2001). The Japanese Night Heron Gorsachius goisagi, the Goshawk Accipiter gentilis and the Grey-faced Buzzard Butastur indicus are representative bird species in Japanese rural forests and considered to be threatened (Higuchi et al. 2000, Fujioka \& Yoshida 2001, Kawakami 2002). In order to assess the status of the three species, it is necessary to know whether they are increasing or decreasing in number.

The Japanese Night Heron is classified as Endangered (EN) by BirdLife International (2001), that breeds only in Japan. This species prefers to breed in rural lowland forests

\footnotetext{
Received 8 January 2003, Revised 24 April 2003, Accepted 5 June 2003.

* Tama Forest Science Garden, Forestry and Forest Products Research Institute, Todori 1833, Hachioji, Tokyo 193-0843, Japan. E-mail: kazzto@ffpri.affrc.go.jp

** Laboratory of Biodiversity Science, School of Agriculture and Life Sciences, The University of Tokyo, Yayoi 1-1-1, Bunkyo-ku, Tokyo 113-8657, Japan. E-mail: higuchi@es.a.u-tokyo.ac.jp
} 
nearby paddy fields (Kawakami 2002). This species was thought to have been decreasing in number (BirdLife International 2001, Kawakami 2002), and there were local evidences of decrease on Miyake Island in Tokyo (Brazil 1991), and the Kunado area in Yamanashi Prefecture (Hyuga 1993). Though this species was ranked as near threatened (NT) in the Japanese Red Data Book (RDB, Ministry of the Environment 2002), we consider that it was undervaluation and have need of more conservation efforts. The ecology and conservation of the Japanese Night Heron has not been studied in detail so far.

The Grey-faced Buzzard is a typical bird of prey depending upon the farmland for its habitat and its population is considered to be declining in connection with the decrease and deterioration of SATOYAMA habitat (Azuma et al. 1999, Higuchi et al. 2000, Fujioka \& Yoshida 2001, Momose 2001). The Japanese Night Heron and the Grey-faced Buzzard are summer visitors in Japan, which mainly winter in Southeast Asia (Kiyosu 1978a, 1978b). A decline in summer visitors has been of special concern to many researchers and birdwatchers in Japan (e.g. Endo 1993, Higuchi \& Morishita 1999). But the Grey-faced Buzzard is not categorized in the Japanese RDB (Ministry of the Environment 2002).

The Goshawk was listed as vulnerable species (VU) in the Japanese RDB being at higher rank than the former two (Ministry of the Environment 2002). This species often breeds in more or less fragmented forest habitat of agricultural landscapes (Fujioka \& Yoshida 2001). Fujioka \& Yoshida (2001) described that this species once declined seriously worldwide due to organochlorine pesticides during the 1950s-1970s. Some reports, however, suggested a possibility that it had been increasing in number in some areas expanding its habitat toward urbia (e.g. Morioka et al. 1995, Osaka Prefectural Government, Department of Environment, Agriculture, Forestry and Fisheries, Conservation and Afforestation Office 2002).

Though the population trends of these three species were concerned by researchers (e.g. Higuchi \& Morishita 1999, Kawakami 2002), they are poorly known except for some local and/or short-term reports (Collar et al. 1994, Ministry of the Environment 2002). The reason may be that it is difficult to monitor systematically and extensively the population trends of these birds that occupy large territories. Thus, we tried to estimate their long-term and large-scale population trends indirectly with the records of individuals kept in zoos.

Annual reports of Japan Zoo and Aquarium Association (JAZA), which include the numbers of birds kept at each zoo in Japan, have been published since 1952. They show the number of individuals on December 31 for each year. If target species can satisfy the following conditions, we can assume that captive population trends of a particular species in zoos reflect the wild population trends of the same species. 1) Target species has not been collected with effort by zoos, 2) It has rarely, if ever, been bred in zoological gardens, and 3) The number of injured and brought individuals reflects the abundance of the wild population. To satisfy the first two conditions means that the keeping individuals are the injured and brought ones. In order to complete the third condition, the wild population must occur nearby human inhabited area. If not, the number of rescued individuals reflects only a part of wild population. The three species prefer rural lowland forests where human can easily approach. They are considered to satisfy the above conditions. 
Though the Goshawk and the Grey-faced Buzzard have been breeding in some zoos recently, its number was not so high, under five individuals per year (JAZA 1989, 1996, 1997, 1998, 1999).

We also assessed the population trends of target species at local areas in Japan, in order to reinforce the aforementioned survey. We collected records of the number of rescued individuals that were brought to public facilities and migrating individuals observed at two major migratory stopover points.

In this paper, we estimate the population trends of the three species and discuss their statuses in the Japanese RDB.

\section{Methods}

\section{Zoo records}

In order to estimate the changes in number of individuals kept at zoos, we calculated both total number and annual increment of breeding individuals for each year. We referred to annual reports of JAZA from 1952 to 1999 . First, the numbers of individuals at all zoos were totalized for each year. This value shows the maximum number of newly retrieved individuals for each year. Then, we calculated the annual increment for each zoo and totalized the increments of all zoos for each year; that is, we subtracted the number of individuals in the previous year from one in a certain year for each zoo and summed each value up for each year. When the number became minus, we counted it as zero. This value is the minimum number of newly retrieved individuals for each year, because it is when maximal number of individuals has survived. The actual increase of a certain year should be intermediate between the two values.

We calculated a regression formula between each value and the year. We tested the significance of the regression formula by one-way ANOVA.

There is a possibility that zoos and their records were deficient in the $1950 \mathrm{~s}$, because the society was not stabilized immediately after World War II. As many zoos were established in the 1950s (Ueno Zoological Garden 1982), the number of keeping individuals should have been influenced by the change in number of zoo. We, therefore, used only the records since 1960 for statistical analysis, because the records from the 1950 s were not considered to be credible.

\section{Records of local populations}

We analyzed records of the numbers of rescued individuals that were offered by Niigata Prefectural Bird Protection Center (1985-1999) and Tochigi Prefectural Citizen's Park Management Office (1976-1999). As there was no record of the Japanese Night Heron, we analyzed on the other two species. Statistical tests were carried out as above.

The records of numbers of migrating individuals were obtained from the annual counts at Cape Irago and the Miyako Islands (Kugai 1996, IRAGO Migratory Birds Count Club 2000). There were records of the two raptor species at Cape Irago from 1976 to 1999, while records existed only on the buzzard in the Miyako Islands from 1973 to 1994. Statistical tests were carried out as above. 


\section{Results}

\section{Zoo records}

Since the 1960s, the number of the Japanese Night Heron has significantly declined for each value (Fig. 1; total: $F=100.848, d f=39, P<0.0001$, power $=1.0$, annual increment: $F=32.135, d f=39, P<0.0001$, power $=1.0$ ). On the Grey-faced Buzzard, there was a same tendency (Fig. 2; total: $F=45.94, d f=39, P<0.0001$, power $=1.0$, annual increment: $F=18.907, d f=39, P<0.0001$, power $=1.0$ ). In contrast, the number of the Goshawk kept at zoos significantly increased during the period (Fig. 3; total: $F=195.487$, $d f=39, P<0.0001$, power $=1.0$, annual increment: $F=29.273, d f=39, P<0.0001$, power $=1.0$ ).

\section{Records of local populations}

In Niigata Prefecture, the number of rescued Grey-faced Buzzards had significantly decreased (Fig. $4 ; F=11.65, d f=14, P<0.005$, power $=0.897$ ), while the number of the Goshawk had significantly increased (Fig. $4 ; F=13.91, d f=14, P<0.005$, power $=0.944$ ). In Tochigi Prefecture, the Goshawk had significantly increased in number, too (Fig. 5; $F$ $=56.91, d f=23, P<0.0001$, power $=1.0)$. The Grey-faced Buzzard had also increased in number (Fig. $5 ; F=4.33, d f=23, P=0.0493$, power $=0.501$ ). But the increase was only a slight one and the power was low. Therefore, we can not say that it had surely increased. At Cape Irago, the number of migrating Grey-faced Buzzards had significantly

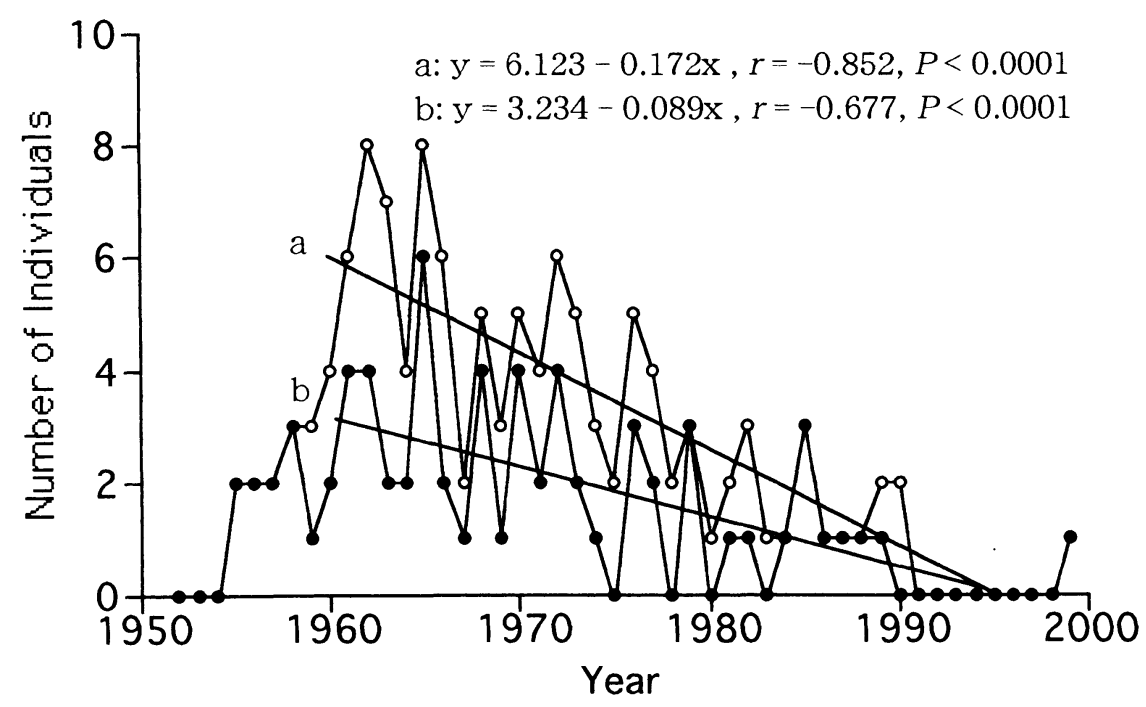

Fig. 1. Annual change in the number of Japanese Night Herons kept at zoological gardens in Japan from 1952 to 1999 . The open and closed circles show the number of individuals and annual increment for each year, respectively. The regression lines were drawn based on the data from $1960(1960$ as 0$)$. 


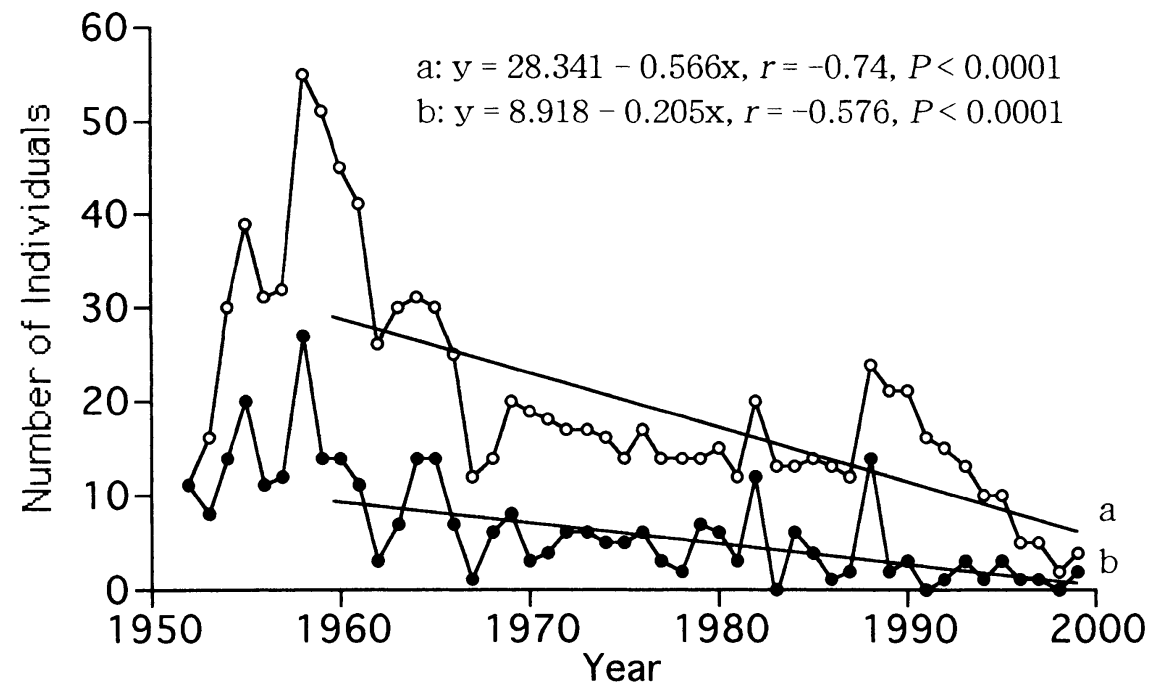

Fig. 2. Annual change in the number of Grey-faced Buzzards kept at zoological gardens in Japan from 1952 to 1999 . The symbols and lines are the same as in Fig. 1.

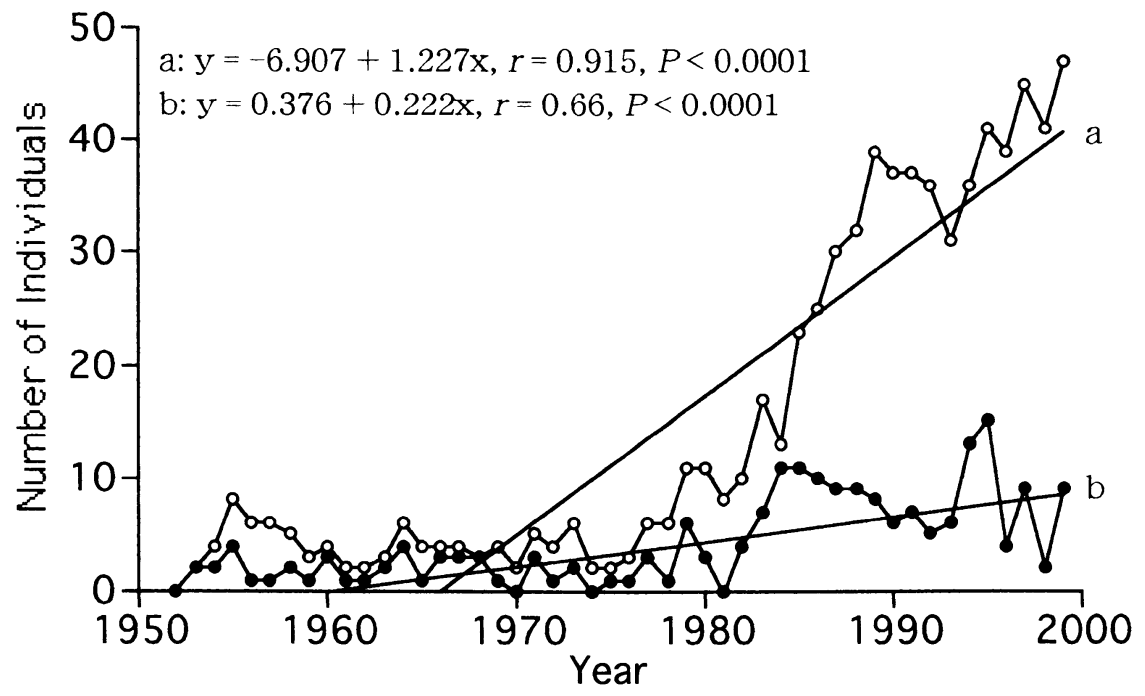

Fig. 3. Annual change in the number of Goshawks kept at zoological gardens in Japan from 1952 to 1999. The symbols and lines are the same as in Fig. 1.

decreased through the survey periods (Fig. $6 ; F=5.63, d f=23, P<0.05$, power $=0.618$ ), while the number of the Goshawk had significantly increased (Fig. 6; $F=30.49, d f=23$, $P<0.0001$, power $=1.0$ ). The power on the Grey-faced Buzzards was low, probably because of the large annual change and relative small sample size. According to the formula showed in Fig. 6, the number of the Goshawk had almost become eleven times as 


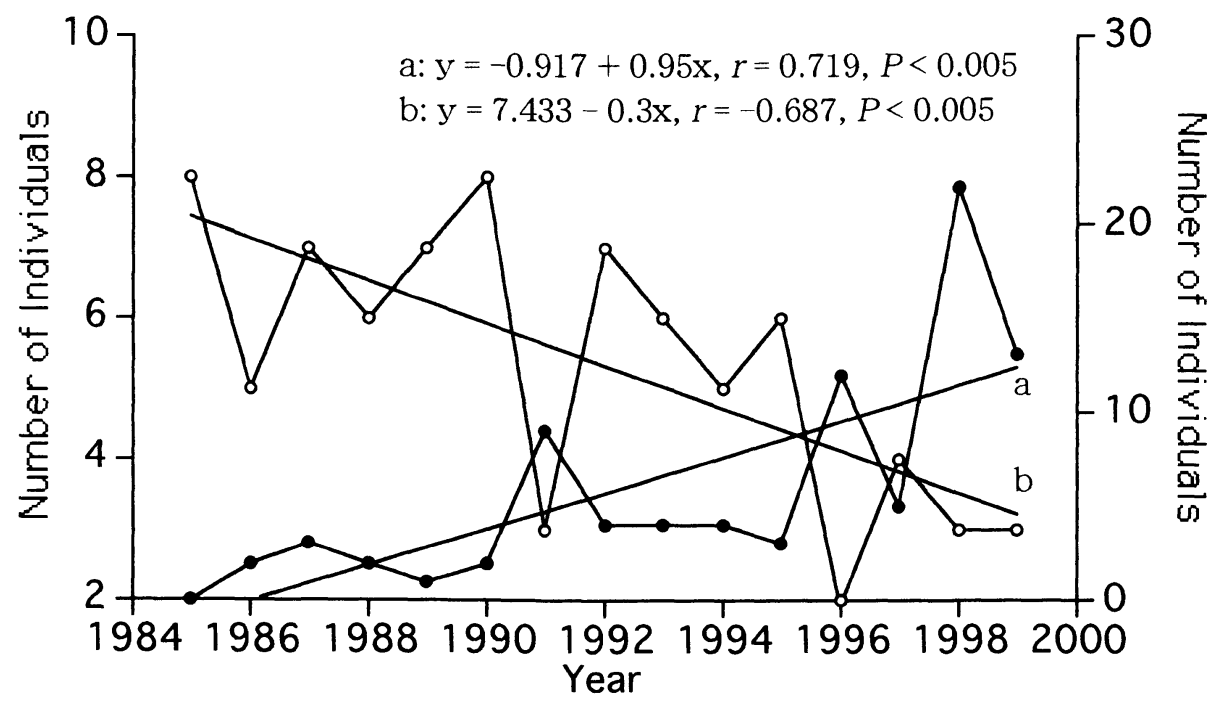

Fig. 4. Annual change in the number of Grey-faced Buzzards and Goshawks that were injured and brought to Niigata Prefectural Bird Protection Center from 1985 to 1999. The open and closed circles show the number of Grey-faced Buzzards (left y-axis) and Goshawks (right y-axis), respectively. The lines are regression lines (1985 as 0). Original data were provided by Niigata Prefectural Bird Protection Center.

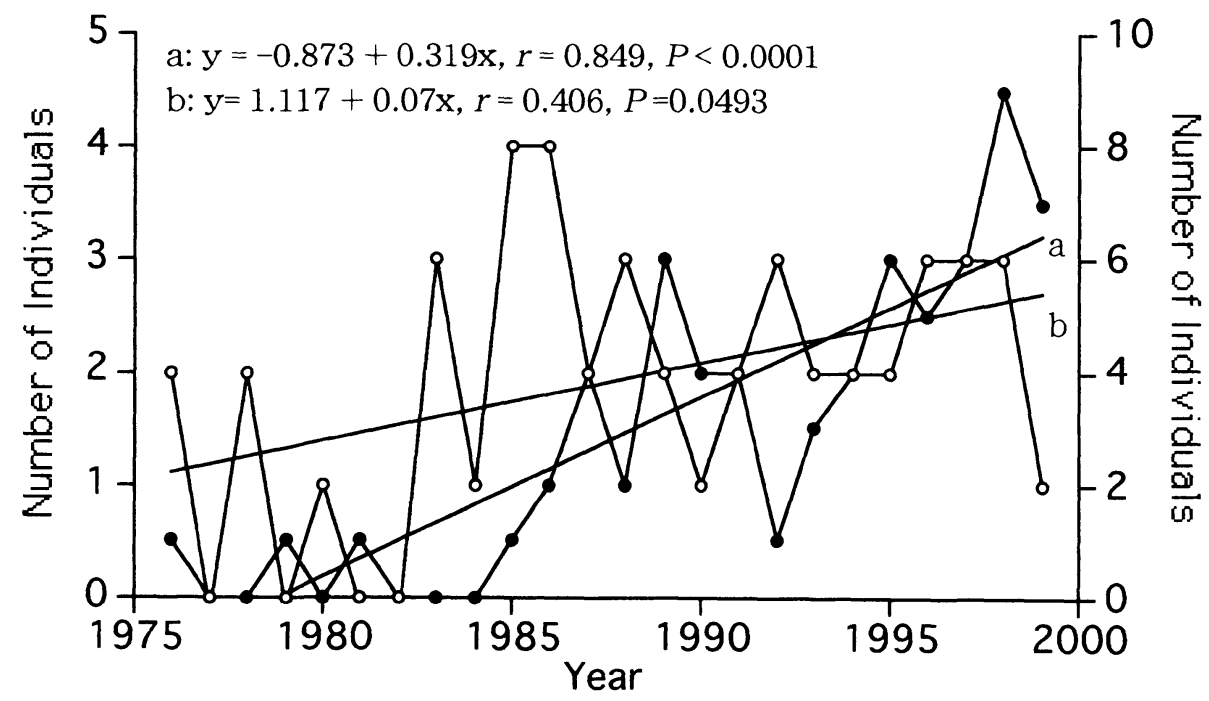

Fig. 5. Annual change in the number of Grey-faced Buzzards and Goshawks that were injured and brought to Tochigi Prefectural Citizen's Park Management Office from 1976 to 1999. The symbols are the same as in Fig. 4. The lines are regression lines (1976 as 0). Original data were provided by Tochigi Prefectural Citizen's Park Management Office. 


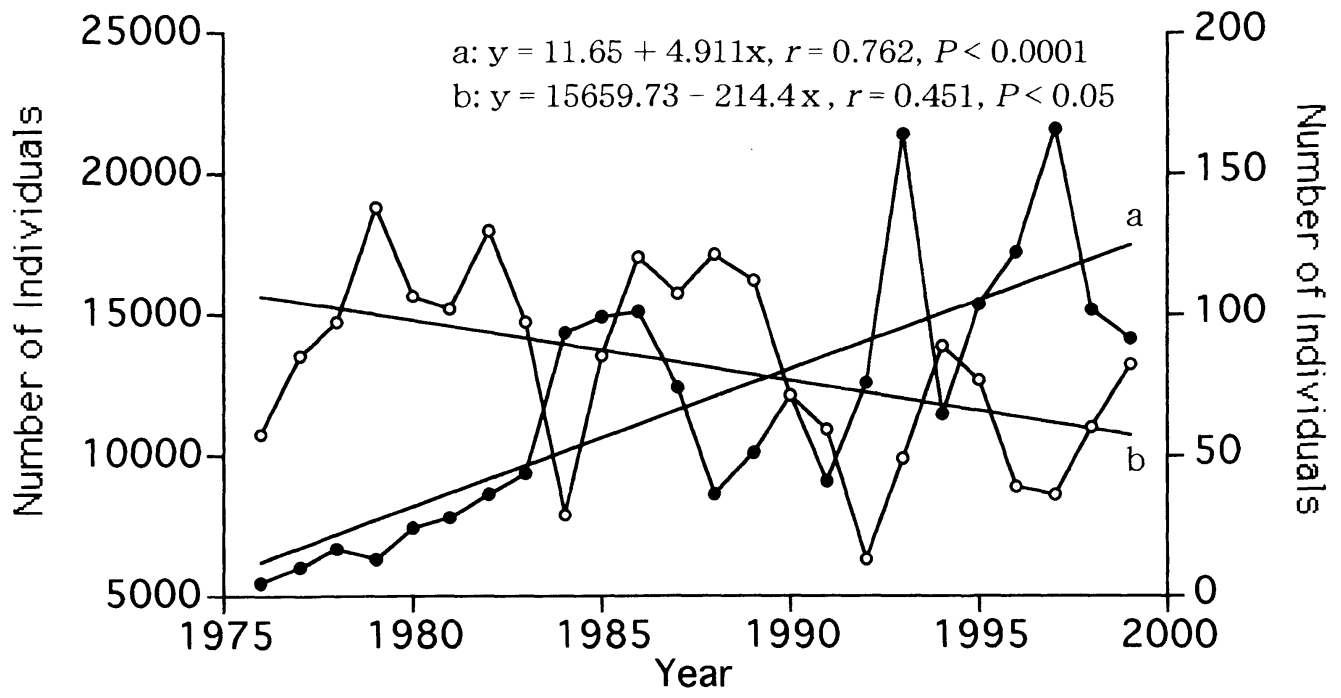

Fig. 6. Annual change in the number of Grey-faced Buzzards and Goshawks observed at Cape Irago from 1976 to 1999 . The symbols are the same as in Fig. 4. The lines are regression lines (1976 as 0). The original census data were taken from IRAGO Migratory Birds Count Club (2000).

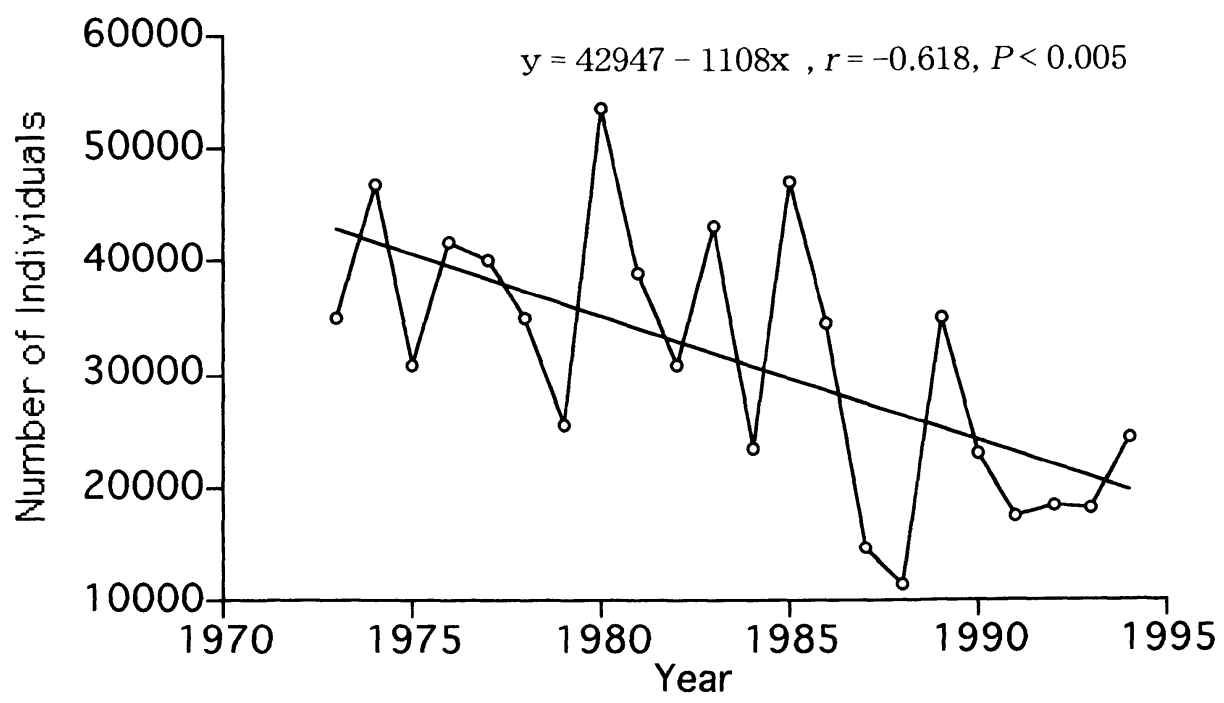

Fig. 7. Annual change in the number of Grey-faced Buzzards observed in the Miyako Islands from 1973 to 1994 . The line is a regression line (1973 as 0$)$. The original census data were taken from Kugai (1996).

much during the survey period. In the Miyako Islands, the Grey-faced Buzzard showed the same tendency (Fig. $7 ; F=12.37, d f=21, P<0.005$, power $=0.932$ ). The population size of the Grey-faced Buzzard had been almost dimidiated during the survey period. 


\section{Discussion}

The results showed that the number of the Japanese Night Heron kept at zoos has intensively decreased since the 1960s. This probably reflects a decline of the wild population. This tendency coincides with the reports of Brazil (1991) and Hyuga (1993), who suggested local population declines of the species in Miyake Island and the Kunado area, respectively.

The zoo population of the Grey-faced Buzzard has also decreased since the 1960s. The results in Niigata Prefecture, Cape Irago and the Miyako Islands showed same decreasing trends since the 1970s, while it had not decreased in Tochigi Prefecture. As the records of JAZA and migration numbers reflect the population of wide areas, it is likely that it has declined on a nationwide scale. The population trend might be not homogeneous across its range, and population declination might have not occurred exceptionally in some areas. Indeed, in some areas in Tochigi Prefecture, relative many individuals are still maintained even today. But then, we can suggest another possibility that contradicts the increase in Tochigi Prefecture. Because the decline of individuals kept in zoos started in the 1960 s, there is a possibility that the population had already decreased before the 1970s in Tochigi Prefecture. The increase in Tochigi Prefecture was, however, very small and the statistical power was low. Thus the local trend might be mistaken. In any case, it is undoubted that the Grey-faced Buzzard has decreased nationwidely.

There is a possibility that the Grey-faced Buzzard has expanded its wintering habitat area toward the north. It might influence the population decline in the Miyako Islands. It is estimated that it has recently ranged to the mainland of Kagoshima Prefecture in winter (Kawakami \& Higuchi unpublished data). The population size, however, is not so large, at most dozens or hundreds of individuals, and it is only a few beside the decrease in the number of migrating individuals in the Miyako Islands. Therefore, this factor does not influence the population trend in the islands.

Both the Japanese Night Heron and the Grey-faced Buzzard prefer rural forests as their breeding habitats and agricultural lands near forests as their feeding habitats (Azuma et al. 1999, Kawakami 2002). Recently, such SATOYAMA habitat has been deteriorating quantitatively and qualitatively (Takeuchi et al. 2001). The Japanese Night Heron mainly forages soil animals such as earthworms and small freshwater crabs (Kawakami, K. unpublished data), while the Grey-faced Buzzard prefers reptiles, small mammals and insects (Kiyosu 1978b). Such animals are considered to have been decreased due to deforestation and the arrangement of farmland (Hasegawa 2000, Takeuchi et al. 2001). Thus, food decline must be one of the factors that have caused the population decline. At the same time, intensive forest destruction had occurred in their wintering habitats, mainly Southeast Asia (e.g. Kummer 1991, Mackinnon \& Phillipps 1994, Higuchi \& Morishita 1999). This is probably another major reason of their declines.

In contrast to these two species, the number of the Goshawk at zoos has significantly increased, with all local records showing the same tendency. Those results suggest that the wild population of the species had been increasing in Japan. This tendency is consistent 
with some local reports that suggested the same trends (e.g. Tokyo Metropolitan Government, Bureau of Environment 1998, Hamaguchi 2000). Morioka et al. (1995) suggested that the Goshawk might have been expanding its distribution since about 1980. Hisatake (2002) described that the area where injured Goshawks were found had expanded in Tochigi Prefecture since 1989.

There is a possibility that we overestimated the number of the three species at zoo. First, since more attention has been given to the conservation of wildlife during last few decades, finding efficiency might have increased. Secondly, an increase in number of zoological parks (JAZA 1952-1999) may have raised the number of rescued individuals. Thirdly, advancements in techniques for caring for captured birds might be increasing their longevity.

Therefore, the increase in number of kept and rescued Goshawk does not mean that its wild population has increased at the same rate. The large difference between the total numbers and the increment number of the Goshawk may be the result of the third effect. At the same time, since injured individuals would be rescued more frequently near residential areas than in outback forests, the increase in number of captive individuals might reflect only the suburban population. The population trend in outback forests is unclear as the case stands. It is necessary to investigate the trend of the wild population in detail.

In spite of the possibility of overestimation, the Japanese Night Heron and the Gray-faced Buzzard has decreased in number at zoos. It strongly suggests that the wild population should also have decreased. The slightly increase of this species in Tochigi Prefecture might be overestimated.

Though the Japanese Night Heron was listed in the Japanese RDB (Ministry of the Environment 2002), its status of NT is considered to be underestimation. Our results showed that the evaluation as EN by the BirdLife International (2001) is more valid, because the species had declined intensively for last few decades. Taking stock of the situation, the Ministry of the Environment has to raise its rank to EN. And the Grey-faced Buzzard should be assessed more seriously and listed in the RDB.

The two raptor species showed opposite tendencies in their population trends. It might seem that the Goshawk excluded the Grey-faced Buzzard. The latter, however, decreased in the 1960s, while the former increased in the 1980s. Therefore, it is reasonable that the Goshawk raised its population after the Grey-faced Buzzard disappeared by other reasons such as habitat loss and the decline of food supply.

So far, the Japanese Night Heron and the Grey-faced Buzzard have not really been a target of conservation. The two species strongly rely on rural SATOYAMA habitat, which is steadily being destroyed. Moreover, their distribution is not so wide, being limited to the Far East. Such a situation highlights the importance of conservation on these two species.

\section{Acknowledgments}

We specially thank Tatsuo Kazama and Toshiya Hisatake for offering the data of the 
number of rescued raptor species at Niigata and Tochigi Prefecture, respectively. We are grateful to Teruyuki Komiya, Kyoko Yamaguchi, Yuko Ogawa, Sumire Sakai, Masaki Fujita, Ken-ichi Tokita, Atsuki Azuma, Emiko Morishita, Eri Fujioka, Wakako Taniguchi, Tochigi Prefectural Citizen's Park Management Office, the Tama Zoological Park, the Ueno Zoological Gardens, the Asahiyama Zoo, the Morioka Zoological Park, the Yagiyama Zoological Park and the Fukuoka Municipal Zoo for their helpful comments and useful information.

\section{References}

Azuma, A., Tokita, K., Takeuchi, K. \& Tsunekawa, A. 1999. Land condition of Gray-faced Buzzard, Butastur indicus in watershed of Tega Mersh, Chiba Prefecture. Journal of Rural Planning Association 1: $253-258$. (in Japanese with English summary)

BirdLife International. 2001. Japanese Night Heron. In Threatened Birds of Asia: the BirdLife International Red Data Book Part A (eds. N. J. Collar, A. V. Andreev, S. Chan, M. J. Crosby, S. Subramanya \& J. A. Tobias), pp. 153-168. BirdLife International, Cambridge.

Brazil, M. 1991. The Birds of Japan. Christopher Helm Ltd., London.

Collar, N. J., Crosby, M. J. \& Stattersfield, A. J. 1994. Birds to Watch 2: The world list of threatened birds. BirdLife International, Cambridge.

Endo, K. (ed.) 1993. How are the Songs of Summer Visitors, Now ? Sanseido Publishing, Tokyo. (in Japanese)

Fujioka, M. \& Yoshida, H. 2001. The potential and problems of agricultural ecosystems for birds in Japan. Global Environmental Research 5: 151-161.

Hamaguchi, T. 2000. Status of Goshawk population and the transition of problems on conservation in Kanagawa prefecture. In Reports on the Raptors in Kanagawa Prefecture (ed. Kanagawa Wildlife Research Group), pp. 39-43. Yume Kobo, Kanagawa. (in Japanese)

Hasegawa, M. 2000. Amphibians and reptiles in danger. Animals and Zoos 52: 120-123. (in Japanese)

Higuchi, H. \& Morishita, E. 1999. Population declines of tropical migratory birds in Japan. Actinia 12: 51-59.

Higuchi, H., Morishita, E., Azuma, A., Tokita, K., Uchida, H., Tsunekawa, A. \& Takeuchi, K. 2000. Satellite tracking the migration of Gray-faced Buzzards and analysis of habitat selection on wintering grounds. Bulletin of Abiko City Museum of Birds 8: 25-36. (in Japanese)

Hisatake, T. 2002. The Goshawks rescued as injured individuals. Bulletin on Wildlife in Tochigi Prefecture 28: 85-89. (in Japanese)

Hyuga, F. 1993. What has got the delectation of contacting summer visitors. In How are the Songs of Summer Visitors, Now? (ed. K. Endo), pp. 144-146. Sanseido Publishing, Tokyo. (in Japanese)

IRAGO Migratory Birds Count Club. 2000. The hawk migration at Cape Irago. In Hawk Migration in Japan 2000 (ed. the executive committee of Raptor Migration Symposium 2000), pp. 36-46. (in Japanese)

JAZA (Japan Zoo and Aquarium Association). 1952-1999. Annual Reports of Japan Zoo Aquarium Association (1952-1999). JAZA, Tokyo. (in Japanese)

Kawakami, K. 2002. The possibility of extinction on Japanese Night Heron. Wild birds 67(6): 13-15. (in Japanese)

Kiyosu, Y. 1978a. The Birds of Japan II. Kodansha, Tokyo.

Kiyosu, Y. 1978b. The Birds of Japan III. Kodansha, Tokyo.

Kugai, K. 1996. Autumnal migration of Grey-faced Buzzard Butastur indicus in Japan. Proceedings of Okinawa Prefectural Museum 22: 153-172.

Kummer, D. M. 1991. Deforestation in the Postwar Philippines. Ateneo de Manila University Press, Manila.

Mackinnon, J. \& Phillipps, K. 1994. A Field Guide of the Birds of Borneo, Sumatra, Java and Bali. Oxford University Press, New York.

Ministry of the Environment. 2002. Threatened Wildlife of Japan -Red Data Book 2nd ed. - vol. 2 Aves. Japan Wildlife Research Center, Tokyo. (in Japanese) 
Momose, H. 2001. Analysis of animal habitat utilizing Geographical Information System. Japanese Journal of Ecology 51: 239-246. (in Japanese with English summary)

Morioka, T., Yamagata, N., Kanouchi, T. \& Kawata, T. 1995. The Birds of Prey in Japan. Bun-Ichi Co. Ltd., Tokyo. (in Japanese)

Osaka Prefectural Government, Department of Environment, Agriculture, Forestry and Fisheries, Conservation and Afforestation Office. 2002. Reports on the Distribution and Status of Goshawks and Mountain Hawk Eagles. Osaka Prefecture, Osaka. (in Japanese)

Takeuchi, K., Washitani, I. \& Tsunekawa, A. 2001. SATOYAMA: The Traditional Rural Landscape of Japan. University of Tokyo Press, Tokyo. (in Japanese)

Tokyo Metropolitan Government, Bureau of Environment. 1998. Reports on the State of Breeding Birds in Tokyo. Tokyo Metropolitan Government, Tokyo. (in Japanese)

Ueno Zoological Garden. 1982. The Centennial History of Ueno Zoological Garden. Dai-ichi Hoki Press, Tokyo. (in Japanese)

Washitani, I. 2001. Traditional sustainable ecosystem 'SATOYAMA' and biodiversity crisis in Japan: Conservation ecological perspective. Global Environmental Research 5: 119-133.

\section{日本の低山に生息するミゾゴイ Gorsachius goisagi，オオタカ Accipiter gentilis， サシバ Butastur indicus の個体数推移の推定}

動物園の飼育個体数の記録を用いて, ミゾゴイ, オオタカ, サシバの 1960 年代以後の個体数 推移の推定を行った。これらの種は, 動物園で積極的に収集している種ではなく, また飼育下 での繁殖もほとんどされていない。そこで, 飼育個体数は保護個体数を, 保護個体数は野生個 体数を反映していると仮定した。また，これらのデータを補強するため，新潟，杤木，伊良湖 岬, 宮古諸島での個体数推移の記録を収集し検討した。その結果, ミゾゴイとサシバは 1960 年 代以後, 全国的に減少していることが示唆された。これに対しオオタカは全国的に増加傾向が 見られた。ただし, 飼育個体数で評価したため, 過大評価の可能性があり, 今後野生個体群に 関して詳細に検討していく必要がある。ミゾゴイとサシバの減少は, 生息地や食物資源, 越冬 地の森林の減少等が原因と考えられる。この 2 種はこれまで保全上あまり注目されてこなかっ たが，レッドデータブックでの地位を上げ，保全に積極的に取り組んでいく必要がある。

川上和人：森林総合研究所多摩森林科学園． $=193-0843$ 東京都八王子市廿里町 1833.

樋口広芳: 東京大学大学院農学生命科学研究科生物多様性研究室. 干113-8657 東京都文京 区弥生 1-1-1. 